\title{
PETA KONSEP SEBAGAI STRATEGI MENINGKATKAN HASIL BELAJAR SISWA SEKOLAH DASAR
}

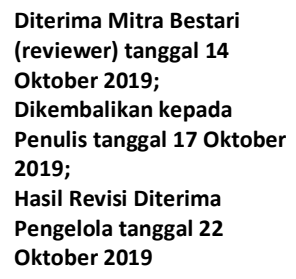

\begin{abstract}
Abstrak
Tujuan dari penelitian ini adalah bagaimana cara menggunakan strategi pembelajaran peta konsep (concept mapping) untuk meningkatkan hasil belajar siswa Sekolah Dasar. Metode yang digunakan adalah penelitian pustaka. Penelitian ini dilatarbelakangi oleh cara guru mengajar yang masih konvensional dengan ceramah, Hal ini berdampak pada minat belajar anak yang kurang sehingga hasil belajar siswa rendah. Maka guru dituntut untuk mampu menerapkan strategi pembelajaran inovatif. Peta konsep dapat menjadi solusi bagaimana menciptakan suatu pembelajaran bermakna pada siswa dalam pembelajaran tematik. Dalam peta konsep, belajar menjadi bermakna karena pengetahuan atau informasi baru dengan pengetahuan terstruktur yang telah dimiliki siswa tersambung sehingga menjadi lebih mudah terserap siswa, tidak membuat siswa cepat bosan karena cara penulisan yang efektif, efisien dan menghemat tempat,serta membuat siswa lebih bebas berkreasi sehingga hasil belajar siswa meningkat.
\end{abstract}

Kata kunci : strategi pembelajaran, peta konsep, hasil belajar

\section{A. PENDAHULUAN}

\section{Latar Belakang}

Pembelajaran pada kurikulum

2013 berbeda dengan pembelajaran yang dilakukan pada kurikulum KTSP. Pada kurikulum 2013 pembelajaran bersifat tematik dimana semua mata pelajaran digabung menjadi satu kegiatan pembelajaran, namun penilaian tetap kembali pada muatan mata pelajaran.

Sifat penilaian yang masih permuatan menjadikan guru kesulitan dalam proses penerapan yang holistik dalam pembelajaran. Sehingga guru harus pandai membuat strategi yang kegiatan pembelajarannya diharapkan sesuai dengan harapan dari kurikulum 2013.

Pada kurikulum 2013, guru dituntut untuk mengajarkan siswa berpikir holistik, tetapi tetap memahami karakteristik siswa. Hal tersebut berdampak pada proses pembelajaran sehingga guru perlu memiliki strategi pembelajaran yang tepat untuk siswa yang pembelajaran di kelas bersifat tematik, dapat dipahami dengan mudah oleh siswa. Strategi pembelajaran yang tepat memberikan pengaruh yang besar terhadap proses pembelajaran.

Guru sebagai tenaga pendidik berperan penting dalam memberikan 
pengetahuan kepada siswa sehingga memiliki penguasaan pengetahuan dan keterampilan hidup yang dibutuhkan dalam menghadapi kehidupan nyata. Namun pada kenyataannya proses pembelajaran yang dilakukan guru masih belum berjalan secara maksimal. Salah satu penyebabnya adalah cara guru mengajar yang masih konvensional dengan ceramah, menjelaskan materi di depan kelas, berorientasi pada buku, dan melakukan tanya jawab dengan siswa yang bisa atau aktif di dalam kelas. Hal ini membuat proses pembelajaran didominasi oleh guru dan beberapa siswa saja. Sedangkan bagi siswa yang pasif, tidak memiliki banyak peran dalam proses pembelajaran. Metode ceramah yang digunakan guru dalam menyampaikan materi dapat membuat pembelajaran menjadi membosankan. Siswa kurang diberi kesempatan untuk menyusun pengetahuannya sendiri dalam proses pembelajaran. Keadaan tersebut membuat siswa berpikir bahwa apa yang mereka pelajari di kelas tidak bermakna bagi kehidupannya . Hal ini berdampak pada minat belajar anak yang berkurang sehingga hasil belajar siswa rendah.

Strategi pembelajaran merupakan bagian yang sangat penting dalam kegiatan pembelajaran, sebab jika guru menerapkan strategi pembelajaran yang tepat dengan materi dan media pembelajaran, maka akan dapat meningkatkan keefektifan pembelajaran dalam mencapai tujuan pembelajaran. Guru dalam hal ini dituntut untuk mampu menerapkan strategi pembelajaran dengan menyesuaikan materi dan juga tujuan pembelajaran. Strategi pembelajaran inovatif menjadi hal yang krusial dilakukan oleh guru. Inovasi guru dalam menerapkan strategi pembelajaran menjadi hal yang penting, sebab dengan guru menerapkan inovasi dan variasi strategi pembelajaran setiap pertemuan dalam pembelajaran, diharapkan dapat meningkatkan motivasi belajar dan prestasi belajar siswa serta meminimalisasi kebosanan siswa dalam pembelajaran.

Kunci dalam sebuah pembelajaran adalah pemahaman konsep yang baik. Untuk mendalami sebuah konsep baru, siswa terlebih dahulu memahami konsep pada materi sebelumnya. Hal ini merupakan syarat bagi siswa agar dapat menerima dan memahami konsep baru dengan mudah. Dengan kurangnya pemahaman siswa terhadap materi yang disampaikan meyebabkan hasil belajar tidak maksimal dan tidak mencapai ketuntasan belajar (Kamarianto, dkk, 2018).

Berdasarkan uraian tersebut, penulis akan membahas tentang strategi pembelajaran yang merupakan salah satu cara untuk meningkatkann hasil belajar siswa. Maka penulis mengambil judul 
penelitian, Peta Konsep (Concept Mapping) sebagai Strategi Meningkatkan Hasil Belajar Siswa Sekolah Dasar.

\section{Rumusan Masalah}

Adapun rumusan permasalahan untuk penelitian ini adalah bagaimanakah cara menggunakan strategi pembelajaran peta konsep (concept mapping) untuk meningkatkan hasil belajar siswa Sekolah Dasar?

\section{Tujuan Penelitian}

Tujuan dari penelitian ini adalah bagaimana cara menggunakan strategi pembelajaran peta konsep (concept mapping) unruk meningkatkan hasil belajar siswa Sekolah Dasar.

\section{Metode}

Metode yang digunakan dalam penelitian ini adalah penelitian pustaka.

\section{B. KAJIAN TEORI}

\section{Strategi Pembelajaran}

Dalam dunia pendidikan, strategi bisa diartikan sebagai a plan, method, or series of activities designed to achieves a particular education goal. Jadi strategi pembelajaran adalah sebuah perencanaan yang berisi tentang rangkaian kegiatan yang didesain untuk mencapai tujuantujuan pendidikan tertentu.

Strategi pembelajaran merupakan upaya mengaktualisasikan berbagai gagasan yang telah dirancang dengan memodifikasi dan memberikan perlakuan yang selaras dan bersiasat sehingga komponen-komponen pembelajaran berfungsi mengembangkan potensi siswa.

Bisa juga dikatakan bahwa strategi pembelajaran adalah rencana dan cara mengajar yang akan dilakukan guru dengan menetapkan langkah-langkah utama mengajar sesuai dengan tujuan pengajaran yang akan dicapai dan telah digariskan.

Menurut Sanjaya

(2012:126) strategi pembelajaran diartikan sebagai perencanaan yang berisi tentang rangkaian kegiatan yang didesain untuk mencapai tujuan pendidikan tertentu.

Kemp

(Wena:2009:5)

mengemukakan bahwa strategi pembelajaran adalah suatu kegiatan pembelajaran yang harus dikerjakan guru dan siswa agar tujuan pembelajaran dapat dicapai secara efektif dan efisien.

Kozma dalam ghofur (1989:91) Strategi pembelajaran dapat diartikan sebagai yang dipilih, yaitu yang dapat memberikan fasilitas atau bantuan kepada peserta didik menuju tercapainya tujuan pembelajaran tertentu.

Martono (2005:41) berpendapat bahwa Strategi pembelajaran merupakan suatu upaya maksimal yang harus ditempuh guru dan siswa dalam pembelajaran untuk menghasilkan kompetensi yang maksimal. 
Sedangkan Syaiful Bahri Djamarah

(2006: 5) Mendefinisikan strategi pembelajaran sebagai suatu pola-pola umum kegiatan guru anak didik dalam perwujudan kegiatan belajar mengajar untuk mencapai tujuan yang telah digariskan.

Jadi berdasarkan definisi diatas dapat disimpulkan strategi pembelajaran merupakan suatu rancangan kegiatan pembelajaran yang disusun guna mencapai tujuan pendidikan yang telah ditentukan yang didalamnya mencakup pendekatan, model, metode dan teknik pembelajaran secara spesifik.

\section{Macam-macam Strategi Pembelajaran}

Menurut Sanjaya (2007 : 177 -

286) ada beberapa macam strategi pembelajaran yang harus dilakukan oleh seorang guru :

1. Strategi pembelajaran ekspositori

Strategi pembelajaran ekspositori adalah strategi pembelajaran yang menekankan kepada proses penyampaian materi secara verbal dari seorang guru kepada sekelompok siswa dengan maksud agar siswa dapat menguasai materi pelajaran secara optimal. Strategi pembelajaran ekspositori merupakan bentuk dari pendekatan pembelajran yang berorientasi kepada guru, dikatakan demikian sebab dalam strategi ini guru memegang peranan yang sangat penting atau dominan.

2. Strategi pembelajaran inquiry Pembelajaran inquiry adalah rangkaian kegiatan pembelajaran yang menekankan pada proses berpikir secara kritis dan analisis untuk mencari dan menemukan sendiri jawaban dari suatu masalah yang dipertanyakan. Proses berpikir itu sendiri biasanya dilakukan melalui tanya jawab antara guru dan siswa. Strategi pembelajaran ini sering juga dinamakan strategi heuristik, yang berasal dari bahasa Yunani yaitu heuriskein yang berarti "saya menemukan". Strategi pembelajaran inquiry merupakan bentuk dari pendekatan pembelajaran yang berorientasi kepada siswa (student centered approach). Dikatakan demikian karena dalam strategi ini siswa memegang peran yang sangat dominan dalam proses pembelajaran.

3. Strategi pembelajaran berbasis masalah

Pembelajaran berbasis masalah dapat diartikan sebagai rangkaian aktivitas pembelajaran yang menekankan kepada proses penyelesaian masalah yang dihadapi secara ilmiah

4. Strategi pembelajaran peningkatan kemampuan berpikir 
Strategi pembelajaran peningkatan kemampuan berpikir merupakan strategi pembelajaran yang menekankan kepada kemampuan berpikir siswa. Dalam pembelajaran ini materi pelajaran tidak disajikan begitu saja kepada siswa, akan tetapi siswa dibimbing untuk proses menemukan sendiri konsep yang harus dikuasai melalui proses dialogis yang terus menerus dengan memanfaatkan pengalaman siswa. Model strategi pembelajaran peningkatan kemampuan berpikir adalah model pembelajaran yang bertumpu kepada pengembangan kemampuan berpikir siswa melalui telaahan fakta-fakta atau pengalaman anak sebagai bahan untuk memecahkan masalah yang diajarkan.

5. Strategi pembelajaran kooperatif Model pembelajaran kelompok adalah rangkaian kegiatan belajar yang dilakukan oleh siswa dalam kelompokkelompok tertentu untuk mencapai tujuan pembelajaran yang telah dirumuskan.

6. Strategi pembelajaran CTL Contextual Teaching Learning (CTL) adalah konsep belajar yang membantu guru mengaitkan antara materi yang diajarkan dengan situasi dunia nyata siswa yang mendorong siswa membuat hubungan antara pengetahuan yang dimilikinya dengan penerapannya dalam kehidupan seharihari. Pengetahuan dan keterampilan siswa dapat diperoleh dari usaha siswa mengkontruksikan sendiri pengetahuan dan keterampilan baru ketika ia belajar.

7. Strategi pembelajaran afektif

Strategi pembelajaran afektif memang berbeda dengan strategi pembelajaran kognitif dan keterampilan. Afektif berhubungan dengan nilai (value), yang sulit diukur, oleh sebab itu menyangkut kesadaran seseorang yang tumbuh dari dalam diri siswa. Strategi pembelajaran afektif pada umumnya menghadapkan siswa pada situasi yang mengandung konflik atau situasi yang problematis. Melalui situasi ini diharapkan siswa dapat mengambil keputusan berdasarkan nilai yang dianggapnya baik.

Ada banyak strategi yang digunakan dalam menerapkan belajar aktif dalam pembelajaran di sekolah, Semuanya dapat diterapkan dalam pembelajaran di kelas sesuai dengan jenis materi dan tujuan yang diinginkan dapat dicapai oleh siswa. Disini kita akan membahas tentang Strategi Pembelajaran Peta Konsep yang dipopulerkan oleh Tony Buzan, seorang ahli dan penulis produktif di bidang psikologi, kreativitas, dan pengembangan diri. 


\section{Konsep dan Peta Konsep}

Menurut Dahar (1988) dalam Trianto (2012:158) konsep adalah suatu abstraksi yang mewakili suatu kelas objekobjek, kejadian-kejadian, kegiatankegiatan, atau hubungan-hubungan yang mempunyai atribut-atribut yang sama.

Trianto (2012:158) dalam Djamarah \& Zain (2002:17) menyebutkan bahwa konsep merupakan kondisi utama yang diperlukan untuk menguasai kemahiran diskriminasi dan proses kognitif fundamental sebelumnya berdasarkan kesamaan ciri-ciri dari sekumpulan stimulus dan objek-objeknya.

Salah satu pernyataan dalam teori Ausubel (dalam Trianto, 2011:94) bahwa faktor yang paling penting memengaruhi pembelajaran adalah apa yang telah diketahui siswa (pengetahuan awal). Supaya belajar jadi bermakna, maka konsep baru harus dikaitkan dengan konsep yang ada dalam struktur kognitif siswa. Melalui peta konsep, diharapkan siswa lebih mudah memahami materi dalam pembelajaran tematik sehingga memaksimalkan dalam proses belajar siswa. Ibrahim (1996), mengemukakan bahwa belajar dengan cara menghafal merupakan kegiatan belajar yang menekankan penguasaan pengetahuan atau fakta-fakta tanpa memberi arti terhadap pengetahuan atau fakta tersebut. Belajar bermakna akan berlangsung bila konsep atau pengertian konsep-konsep diurutkan dari yang paling inklusif secara hierarki ke yang kurang inklusif sampai kepada bagian-bagian atau hal-hal yang khusus. Peta konsep dapat menjadi solusi bagaimana menciptakan suatu pembelajaran bermakna pada siswa dalam pembelajaran tematik.

Peta konsep adalah suatu alat yang digunakan untuk menyatakan hubungan yang bermakna antara konsep-konsep dalam bentuk proposisi-proposisi. Proposisi-proposisi merupakan dua atau lebih konsep-konsep yang dihubungkan oleh kata-kata dalam suatu unit semantik" (Dahar, 1989:122). Bentuk paling sederhana dari suatu peta konsep hanya terdiri atas dua konsep yang dihubungkan oleh satu kata penghubung untuk membentuk suatu proposisi dan berkaitan satu sama yang lain. Menurut Ausubel (1968) dalam Dahar (1989:123) belajar bermakna lebih mudah berlangsung apabila konsep baru yang lebih khusus dikaitkan dengan konsep lama yang lebih umum yang sudah ada dalam struktur kognitif siswa. Tidak semua konsep memiliki bobot yang sama. Hubungan antara konsep-konsep bagi seseorang itu adalah idiosin-kratik, yang artinya kebermaknaan konsep-konsep itu khas bagi setiap orang (Dahar,1989) sehingga peta konsep yang dibuat oleh masingmasing orang akan berbeda. 


\section{Ciri-Ciri Peta Konsep (Concept Mapping)}

Agar pemahaman terhadap peta konsep lebih jelas, Dahar (1989) dalam Erman (2003) dalam Trianto (2009:158), mengemukakan ciri-ciri peta konsep sebagai berikut:

1. Peta konsep atau pemetaan konsep adalah suatu cara untuk memperlihatkan konsep-konsep dan proposisi-proposisi suatu bidang studi, apakah itu bidang studi fisika, kimia, biologi, matematika.

Dengan menggunakan peta konsep, siswa dapat melihat bidang studi itu lebih bermakna.

2. Suatu peta konsep merupakan gambar dua dimensi dari suatu bidang studi. Atau suatu bagian dari bidang studi. Ciri inilah yang dapat memperlihatkan hubungan-hubungan proporsional antara konsep-konsep.

3. Tidak semua konsep mempunyai bobot yang sama. Ini berarti ada konsep yang lebih inklusif dari pada konsep-konsep yang lain.

4. Bila dua atau lebih konsep digambarkan di bawah suatu konsep yang lebih inklusif, terbentuklah suatu hieraki pada peta konsep tersebut.

\section{Macam-Macam Peta Konsep}

Menurut Nur (2000) dalam Erman (2003: 24) peta konsep ada empat macam yaitu: pohon jaringan (network tree), rantai kejadian (events chain), peta konsep siklus (cycle concept map), dan peta konsep laba-laba (spider concept map).

\section{Pohon Jaringan (network tree)}

Ide-ide pokok dibuat dalam persegi empat, sedangkan beberapa kata lain dihubungkan oleh garis penghubung. Kata-kata pada garis penghubung memberikan hubungan antara konsepkonsep. Pada saat mengkonstruksi suatu pohon jaringan, tulislah topik itu dan daftar konsep-konsep utama yang berkaitan dengan topik itu. Daftar dan mulailah dengan menempatkan ide-ide atau konsep-konsep dalam suatu susunan dari umum ke khusus. Cabangkan konsepkonsep yang berkaitan itu dari konsep utama dan berikan hubungannya pada garis-garis itu (Nur dalam Erman 2003: 25) .

Pohon jaringan cocok digunakan untuk memvisualisasikan hal-hal:

a. Menunjukan informasi sebab-akibat

b. Suatu hirarki

c. Prosedur yang bercabang

2. Rantai kejadian (event chain) Nur dalam Erman (2003:26) mengemukakan bahwa peta konsep rantai kejadian dapat digunakan untuk memberikan suatu urutan kejadian, langkah-langkah dalam suatu prosedur, atau tahap-tahap dalam suatu proses. Misalnya dalam melakukan eksperimen. Rantai kejadian cocok 
digunakan untuk memvisualisasikan hal-hal:
a. Memerikan tahap-tahap suatu proses

b. Langkah-langkah dalam suatu prosedur

c. Suatu urutan kejadian

3. Siklus peta konsep (cycle concept mapping)

Dalam peta konsep siklus rangkaian kejadian tidak menghasilkan suatu hasil akhir. Kejadian akhir pada rantai itu menghubungkan kembali ke kejadian awal. Seterusnya kejadian akhir itu menghubungkan kembali ke kejadian awal siklus itu berulang dengan sendirinya dan tidak ada akhirnya. Peta konsep siklus cocok diterapkan untuk menunjukkan hubungan bagaimana suatu rangkaian kejadian berinteraksi untuk menghasilkan suatu kelompok hasil yang berulang-ulang.

4. Peta konsep laba-laba (spider concept map)

Peta konsep laba-laba dapat digunakan untuk curah pendapat. Dalam melakukan curah pendapat ide-ide berasal dari suatu ide sentral, sehingga dapat memperoleh sejumlah besar ide yang bercampur aduk. Banyak dari ideide tersebut berkaitan dengan ide sentral namun belum tentu jelas hubungannya satu sama lain. Kita dapat memulainya dengan memisah- misahkan dan mengelompokkan istilah-istilah menurut kaitan tertentu sehingga istilah itu menjadi lebih berguna dengan menuliskannya di luar konsep utama. Peta konsep laba-laba cocok digunakan untuk memvisualisasikan hal-hal:

a. Tidak menurut hirarki, kecuali berada dalam suatu kategori;

b. Kategori yang tidak parallel;

c. Hasil curah pendapat.

\section{Manfaat dan Tujuan Pembelajaran Peta Konsep}

Pembelajaran dengan menggunakan peta konsep mempunyai banyak manfaat. Ausubel menyatakan dengan jaringan konsep yang digambarkan dalam peta konsep, belajar menjadi bermakna karena pengetahuan atau informasi baru dengan pengetahuan terstruktur yang telah dimiliki siswa tersambung sehingga menjadi lebih mudah terserap siswa (Wahidi, 2010).

Adapun manfaat pembelajaran dengan menggunakan peta konsep yang dinyatakan (Novak \& Gowin, 1985).

1. Bagi Guru

a. Pemetaan konsep merupakan cara terbaik menghadirkan materi pelajaran, hal ini disebabkan peta konsep adalah alat belajar yang tidak menimbulkan efek verbal bagi siswa dengan mudah melihat, membaca, dan mengerti makna yang diberikan;

b. Pemetaan konsep menolong guru memilih aturan pengajaran 
berdasarkan kerangka kerja yang hierarki, hal ini mengingat banyak materi pelajaran yang disajikan dalam urutan yang acak;

c. Membantu guru meningkatkan efisiensi dan efektifitas pengajarannya.

2. Bagi Siswa

a. Pemetaan konsep merupakan cara belajar yang mengembangkan proses belajar bermakna, yang akan meningkatkan pemahaman siswa dan daya ingatnya;

b. Meningkatkan keaktifan dan kreativitas berfikir siswa, hal ini menimbulkan sikap kemandirian belajar yang lebih pada siswa;

c. Mengembangkan struktur kognitif yang terintegrasi dengan baik yang akan memudahkan dalam belajar;

d. Membantu siswa melihat makna materi pelajaran secara lebih komprehensif dalam setiap komponen-komponen konsep dan mengenali hubungan.

Dahar (1989) mengungkapkan tujuan penting penggunaan peta konsep dalam menunjang berlangsungnya proses belajar bermakna yaitu,

1) Menyelidiki apa yang telah diketahui oleh siswa;

2) Mempelajari cara belajar siswa;

3) Mengungkapkan miskonsepsi yang muncul pada siswa;

4) Sebagai alat evaluasi. Selain itu, peta konsep bermanfaat untuk memperoleh skema kognitif dan menargetkan pemahaman konsep yang mendalam.

\section{Sistem Evaluasi}

Evaluasi adalah suatu proses yang sistematis dan berkelanjutan untuk menentukan kualitas (nilai dan arti) dari sesuatu, berdasarkan pertimbangan dan kriteria tertentu dalam rangka pembuatan keputusan. Berdasarkan pengertian ini, ada beberapa hal yang perlu dijelaskan lebih lanjut:

1. Evaluasi adalah suatu proses bukan sukan suatu hasil (product). Hasil yang diperoleh dari kegiatan evaluasi adalah kualitas sesuatu, baik yang menyangkut tentang nilai atau arti, Sedangkan kegiatan untuk sampai pada pemberian nilai dan arti itu adalah evaluasi. Membahas tentang evaluasi berarti mempelajari bagaimana proses pemberian pertimbangan mengenai kualitas sesuatu. Gambaran kualitas yang dimaksud merupakan konsekuensi logis dari proses evaluasi yang dilakukan. Proses tersebut tentu dilakukan secara sistematis dan berkelanjutan, dalam arti terencana, sesuai dengan prosedur dan prinsip serta dilakukan secara terus menerus.

2. Tujuan evaluasi adalah untuk menentukan kualitas sesuatu, terutama yang berkenaan dengan nilai dan arti.

3. Dalam proses evaluasi harus ada pemberian pertimbangan (judgement). Pemberian pertimbangan ini pada 
dasarnya merupakan konsep dasar evaluasi.

4. Pemberian pertimbangan tentang nilai dan arti haruslah berdasarkan kriteria tertentu. Kriteria ini penting dibuat oleh evaluator dengan pertimbangan (a) hasil evaluasi dapat dipertanggungjawabkan secara ilmiah (b) evaluator lebih percaya diri (c) menghindari adanya unsur subjektivitas (d) memungkinkan hasil evaluasi akan sama sekalipun dilakukan pada waktu dan orang yang berbeda (e) memberikan kemudahan bagi evaluator dalam melakukan penafsiran hasil evaluasi.

\section{Alat Evaluasi}

1. Tes

Banyak alat atau instrumen yang dapat digunakan dalam kegiatan evaluasi. Salah satunya adalah tes. Istilah tes tidak hanya popular di lingkungan persekolahan tetapi juga di luar sekolah dan masyarakat umum. Berdasarkan jumlah peserta didik, tes hasil belajar dibedakan menjadi, yaitu tes kelompok dan tes perorangan. Dilihat dari cara penyusunannya, tes dibagi dua jenis, yaitu tes buatan guru (teacher-made test) dan tes yang dibakukan (standardized test). Berdasarkan aspek penghetahuan dan keterampilan, maka tes dapat dibagi menjadi dua jenis yaitu tes pengetahuan (power test) dan tes kecepatan (speed test). Tes dilihat dari bentuk jawaban dibedakan menjadi tiga jenis, yaitu tes tertulis, tes lisan, dan tes perbuatan. Tes secara tertulis dibagi menjadi dua bagian yang terdiri dari tes uraian (uraian bebas dan uraian terbatas) dan tes objektif (benarsalah, pilihan ganda, menjodohkan, melengkapi).

2. Non-Tes

Selain melalui tes, evaluasi juga dapat dilakukan dengan cara non tes. Instrument non-tes dapat kita gunakan jika ingin mengetahui kualitas proses dan produk dari suatu pekerjaan serta hal-hal yang berkenaan dengan domain afektif, seperti sikap, minat, bakat, dan motivasi. Instrumen evaluasi non-tes terdiri dari beberapa cara diantaranya: Observasi (Observation), Wawancara (Interview), Skala Sikap (Attitude Scale), Daftar Cek (Check List), Skala Penilaian (Rating Scale), Angket (Quetioner), Studi Kasus (Case Study),Catatan Insidental (Anecdotal Record), Sosiometri Trianto (2009:164) mengutip pendapat Dahar (1989) dalam Sutowijoyo (2002) mengenai peta konsep sebagai alat evaluasi:

Peta konsep sebagai alat evaluasi didasarkan atas tiga prinsip dalam teori kognitif Ausubel, yaitu: 1) Struktur kognitif diatur secara hierarkis dengan konsep konsep dan proposisi-proposisi yang lebih inklusif, lebih umum, super koordinat terhadap konsep-konsep, dan proposisi-proposisi yang kurang inklusif dan lebih khusus. 2) Konsep-konsep dalam struktur kognitif mengalami diferensiasi 
progresif. Prinsip ini menyatakan bahwa belajar bermakna merupakan proses yang kontinu, di mana konsep konsep baru memperoleh lebih banyak arti dengan dibentuk lebih banyak kaitan-kaitan proposional. Jadi, konsep-konsep tidak pernah tuntas dipelajari, tetap selalu dipelajari, dimodifikasi, dan dibuat lebih inklusif. 3) Prinsip penyesuaian intergratif menyatakan bahwa belajar bermakna akan meningkat bila siswa menyadariakan perlunya kaitan-kaitan baru antara segmen-segmen konsep atau proposisi. Dalam peta konsep penyesuaian integrative ini diperlihatkan dengan kaitan-kaitan saling antara segmensegmen konsep.

Peta konsep bertujuan untuk memperjelas pemahaman suatu bacaan, sehingga dapat dipakai sebagai alat evaluasi dengan cara meminta siswa untuk membaca peta konsep dan menjelaskan hubungan antara konsep satu dengan konsep lain pada satu peta konsep

C. PEMBAHASAN

\section{Langkah-Langkah Membuat Peta Konsep}

Trianto (2009:160) dalam Arends (1997), memberikan langkah-langkah dalam membuat peta konsep sebagai berikut:

1. Mengidentifikasi ide pokok atau prinsip yang melingkupi sejumlah konsep. Contoh: ekosistem;
2. Mengidentifikasi ide-ide atau konsepkonsep sekunder yang menunjang ide utama. Contoh, individu, populasi, dan komunitas;

3. Tempatkan ide-ide utama di tengah atau di puncak peta tersebut;

4. Kelompokkan ide-ide sekunder di sekeliling ide utama yang secara visual menunjukkan hubungan ide-ide tersebut dengan ide utama.

Berdasarkan pendapat Arrends (1997) dapatlah dikemukakan bahwa langkah- langkah dalam membuat peta konsep adalah: (1) memilih suatu bahan bacaan; (2) menentukan konsep-konsep yang relevan; (3) mengurutkan konsepkonsep yang inklusif ke yang kurang inklusif; (4) menyusun konsep-konsep tersebut dalam suatu bentuk gambar, lalu dihubungkan dengan kata penghubung misalnya "terdiri atas", "menggunakan" dan lain-lain.

\section{Hasil Belajar}

Hasil belajar merupakan kulminasi dari suatu proses yang telah dilakukan dalam belajar. Kulminasi akan selalu diiringi dengan kegiatan tindak lanjut. Hasil belajar harus menunjukkan suatu perubahan tingkah laku atau perolehan perilaku yang baru dari siswa yang bersifat menetap, fungsional, positif, dan disadari. Bentuk perubahan tingkah laku harus menyeluruh secara komprehensif sehingga menunjukkan perubahan 
tingkah laku. Aspek perilaku keseluruhan dari tujuan pembelajaran menurut Benyamin Bloom (1956) yang dapat menunjukkan gambaran hasil belajar, mencakup aspek kognitif, afektif, dan psikomotorik. Romizoswki menyebutkan dalam skema kemampuan yang dapat menunjukkan hasil belajar yaitu:

1. Keterampilan kognitif berkaitan dengan kemampuan membuat keputusan memecahkan masalah dan berpikir logis;

2. Keterampilan psikomotor berkaitan dengan kemampuan tindakan fisik dan kegiatan perseptual;

3. Keterampilan reaktif berkaitan dengan sikap, kebijaksanaan, perasaan, dan self control;

4. Keterampilan interaktif berkaitan dengan kemampuan sosial dan kepemiminan.

Gagne (1979) menyebutkan ada lima tipe hasil belajar yang dapat dicapai oleh siswa 1) motor skills; 2) verbal information; 3) intelectual skills; 4) attitudes; dan 5) cognitive strategies.

Untuk melihat hasil belajar yang berkaitan dengan kemampuan berpikir kritis dan ilmiah pada siswa Sekolah Dasar, dapat dikaji proses maupun hasil berdasarkan:

1. Kemampuan membaca, mengamati dan atau menyimak apa yang dijelaskan atau diinformasikan;
2. Kemampuan mengidentifikasi atau membuat sejumlah (sub-sub) pertanyaan berdasarkan substansi yang dibaca, diamati dan atau didengar;

3. Kemampuan mengorganisasi hasilhasil identifikasi dan mengkaji dari sudut persamaan dan perbedaan;

4. Kemampuan melakukan kajian secara menyeluruh.

Pada awalnya akan ada beberapa siswa yang hasil belajarnya masih rendah. Hal ini dikarenakan belum terbiasa dengan strategi peta konsep secara efektif dan efisien akibatnya, saat mengerjakan soal siswa menjadi tidak bisa menjawab dengan baik. Namun pada akhirnya banyak siswa yang berhasil mencapai hasil belajar dengan tercapainya nilai KKM sehingga hasil belajar siswa meningkat.

\section{PENUTUP}

\section{Simpulan}

Berdasarkan penelitian pustaka, diperoleh kesimpulan bahwa penggunaan strategi belajar peta konsep dapat meningkatkan hasil belajar siswa. Pembelajaran peta konsep lebih efektif dan efisien diterapkan pada siswa sekolah dasar. Hal ini dikarenakan strategi belajar peta konsep merupakan pembelajaran yang dapat menguatkan siswa untuk menghadapi persoalan dengan langkah penyelesaian yang sistematis. 
Belajar dengan strategi peta konsep jauh lebih praktis dan siswa tetap memperoleh materi secara luas dan tidak membuat siswa cepat bosan karena cara penulisan yang efektif, efisien dan menghemat tempat. Di samping hal tersebut, strategi belajar peta konsep membuat siswa lebih bebas berkreasi.

\section{Saran}

Seorang guru diharapkan mampu melaksanakan kegiatan pembelajaran dengan menciptakan suasana belajar yang merangsang para siswanya untuk belajar kreatif. Selain itu, guru juga diharapkan lebih berperan sebagai fasilitator yang memfasilitasi kegiatan belajar siswa. Dengan demikian, siswa akan lebih aktif dan kreatif dalam proses pembelajaran.

$\begin{array}{ccc}\text { Dengan } & \text { penerapan } & \text { strategi } \\ \text { pembelajaran } & \text { Peta Konsep (Concept }\end{array}$
Mapping), pembelajaran diharapkan dapat menjadi masukan bagi pendidik untuk meningkatkan profesionalisme pendidik, agar pendidik menjadi lebih aktif, inovatif, kreatif, dan menyenangkan dalam melaksanakan proses belajar mengajar di dalam kelas. Selain itu, diharapkan guru dapat menentukan tentang pentingnya memilih strategi pembelajaran dalam proses pembelajaran di kelas agar lebih menarik, aktif dan diminati siswa hingga akhirnya dapat meningkatkan prestasi atau hasil belajar.

\section{DAFTAR PUSTAKA}

Anitah W., S. d. (2008). Strategi Pembelajaran di SD. Jakarta: Universitas Terbuka.

Asril. (2018). Penerapan Strategi Belajar Peta Konsep (Concept Mapping) Untuk Meningkatkan Hasil Belajar Pkn. Jurnal Primary Program Studi Pendidikan Guru Sekolah Dasar Fakultas Keguruan dan Ilmu Pendidikan, 7(2303-1514).

Cahyono, D. (2012). Retrieved 62, 2019, from areknerut.wordpress.com: https://www.google.com/amp/s/are knerut.wordpress.com

Hajar.dkk. (n.d.). Penerapan Strategi Belajar Peta Konsep Sains Untuk Meningkatkan Hasil Belajar Siswa di Kelas VI. Jurnal Kreatif Tadulako Online, 5.

Suryanto, A. (2009). Evaluasi Pembelajaran di SD. Jakarta: Universitas Terbuka.

Widayanti, A. (2017). Pengaruh Penggunaan Strategi Rangkuman dan Peta Konsep Terhadap Hasil Belajar Kurikulum 2013 pada Siswa Kelas IV. Jurnal Pendidikan, 2(2502-471X), 1639- 